УДК 330.14 DOI: https://doi.org/10.30977/PPВ.2226-8820.2021.27.15

JEL Classification: D24

\title{
УТОЧНЕННЯ СУТНОСТІ КАПІТАЛУ
}

\author{
Бабайлов В. К., канд. економ. наук, доцент \\ Левченко Я.С., доктор філософії з галузі «Соціальні та поведінкові \\ науки", доцент
}

Харківський національний автомобільно-дорожній університет

Постановка проблеми. Капітал - одне 3 найважливіших понять економіки. Однак досі існують різні його трактування. Це значно знижує ефективність економічноїй діяльності. Вся історія економіки і економічної думки свідчить про те, що економіка спрямована ні на що інше, як на вирішення найрізноманітніших проблем господарської діяльності. При цьому можна виділити п’ять основних груп проблем:

- осмислення у Доантичну епоху досвіду усієї господарської діяльності (управління як єдності економіки, інженерії, адміністрації і виробництва);

- відокремлення, визначення в Античну i Середньовічну епохіи основних понять суто економічної діяльності;

- визначення меркантилістами i фізіократами основного джерела створення багатства (вартості) - торгівлі або сільського господарства;

- визначення різними школами економіки ролі держави у господарській діяльності;

- визначення важливих аспектів сочіальної економіки.

Однак серед них існує одна, виключно актуальна проблема, яка й досі притаманна навіть декільком групам економічних проблем - це проблема визначення істиного сенсу капіталу. Вона відома ще з часів Аристотеля. Тому у даному контексті представляє інтерес аналіз останніх досліджень і публікацій щодо вирішення окресленої проблеми.

Аналіз останніх досліджень i публікацій свідчить про наступні трактування сутності капіталу. Так, в джерелі [1] капітал пов'язують виключно 3 додатковою вартістю. В дослідженні [2] автори капіталом вважають усе те, що використовується для виробництва, але безпосередньо не споживається в ньому. На відміну від інших факторів виробництва, капітал складається 3 раніше виробленого продукту. Фактично, будь-які засоби праці класична теорія вважає фізичним капіталом. При цьому підкреслюється, що Карл Маркс вважав неточним ототожнювання капіталу 3 засобами виробництва. Він визначав капітал як «самозростаючу вартість».

В роботі [3] дослідники капіталом вважають однією з фундаментальних економічних категорій, сутність якої досліджується уже протягом століть. Капітал при цьому теж визначається як один із факторів виробництва - усе те, що використовується для виробництва, однак безпосередньо не споживається в ньому (за винятком повільної амортизації). На відміну від іншого фактору 
виробництва, землі й природних ресурсів, капітал складається 3 раніше виробленого продукту. Терміном капітал стали називати у період становлення капіталізму гроші, що їх підприємці вкладали в розвиток свого виробництва 3 метою отримання прибутку. При цьому, на відміну від авторської думки досліджень [1-2], капітал визначається як чинник виробництвва у вигляді вартості, здатної приносити не тільки прибуток, але й збиток.

В праці [3] дослідники також звертають увагу на те, що представники меркантилізму, фізіократів і класичної політекономії теж ототожнювали капітал 3 річчю, із засобами виробництва. Меркантилісти ототожнювали капітал з грішми, фізіократи відносили до капіталу інструменти, сировину й інші речові фактори виробництва. А. Сміт та Д. Рікардо також вважали капіталом засоби виробництва. Згідно теорії трьох факторів виробництва Ж. Б. Сея, капітал - це один із факторів, який приносить його власнику прибуток. Дж. С. Мілль під капіталом розумів попередньо нагромаджений запас продуктів минулої праці. Відмічається також, що у роки Радянського союзу поняття «капітал» не вживали взагалі, а застосовували термін «фонди».

Дослідники праці [4] стверджують, що капітал - це певна сума благ у вигляді матеріальних, грошових i інтелектуальних засобів, що використовуються в якості ресурсу в подальшому виробництві. Тому капітал $\epsilon$ сума так званих капітальних благ, тобто благ з виробництва інших благ. Капітальним благом можна вважати цеглини (3 них складуть будинок), верстати (на них виготовлять деталі майбутніх легкових машин), телевізор (він відтворить телепередачу) тощо. Згідно бухгалтерському визначенню, капіталом називаються всі активи (кошти) фірми.

В дослідженні [5] сутність капіталу розуміють як матеріальні та грошові ресурси, необхідні для розвитку виробництва і створення продукції або послуг. Визначають також форми капіталу за різними сферами застосування, а також три стадї капіталу. Увесь капітал поділяють на основний та оборотний.

На відміну від розуміння сутності капіталу в [1-5], в дослідженні [6] автори наближаються ближче до визначення сутності капіталу, визначають таку його властивість як оборот.

В роботі [7] зазначено ще одне розуміння капіталу та пов'язують його 3 виробничими відносинами. На думку авторів дослідження - це вже аспект капіталу, який пов’язаний не 3 економікою, а 3 індустріальною соціологією. Предметом економіки ніколи не були виробничі відносини, як помилково стверджували радянські політекономи. Суттєвий вплив відчутний у «Капіталі» Маркса. Проте Маркс ніколи, ні на однієї сторінці «Капіталу» не стверджував, що предметом економіки є виробничі відносини; він тільки одного разу і тільки у Передмові до «Капіталу» сказав, що предметом саме його дослідження $\epsilon$ відносини виробництва і обміну.

Невирішені складові загальної проблеми. Підводячи підсумок проведеному аналізу можна констатувати, що досі нема однозначної думки про істинний сенс капіталу. Головна причина цього в тому, що сенс капіталу шукають тільки у частинах, тільки у окремих елементах формули простого 
(тобто, натурального) господарства Гроші-Товар-Гроші (ГТГ), або у окремих елементах формули товарного господарства (ГТГ1). Тому й досі відсутне визначення його важливіших аспектів, якими є сутність $i$ зміст, саме які надають 70\% поняття. Вказані невирішені складові проблеми й визначили мету даного дослідження.

Методики дослідження: Для досягнення поставленої мети в роботі були використані такі загальнонаукові та спеціальні методи і прийоми дослідження: порівняльний аналіз наукової літератури та інформаційних джерел на основі методів порівняння, систематизації та узагальнення; узагальнення результатів аналізу і логічна генерація висновків.

Формулювання мети статті. Метою дослідження $є$ встановлення сутності і змісту капіталу. Для успішного досягнення визначеної мети були окреслені такі задачі: встановити джерела, причини і особливості появи терміну і поняття «Капітал»; оцінити визначення капіталу як вартості різними поколіннями економістів; встановити головне джерело визначення сутності і змісту капіталу.

Виклад основного матеріалу дослідження. При вирішенні першої задачі автори даного дослідження звернули увагу на те, що термін «капітал» з'явився значно раніше поняття «капітал». Термін капітал має давнє походження, яке зовсім не пов'язане с сучасним поняттям капітал, з економікою, з вартістю.

Економічний сенс терміну і поняття капітал, слова капітал виник значно пізніше. Як слідує з літературних джерел, слово «капітал», як єдність терміну і поняття «капітал» запозичене лише напочатку XVIII століття, найімовірніше, 3 німецької мови, де kapital походить від італійського capitale - «основна сума», запозиченого від лат. capitalis - «основний, головний», та від caput «голова». Пізніше - як «головне майно, головна сума» [8]. Тобто, тільки в цей час термін «капітал» набуває економічного сенсу, лише тоді капітал почали пов'язувати 3 вартістю. Але, що це за вартість - це питання не було вирішене.

Для вирішення другої задачі (оцінки визначення капіталу як вартості) був проведений аналіз визначення капіталу як різних вартостей від Аристотеля до наших днів. У літературі відмічається, що першу спробу аналізу двох особливих форм вартості (грошової і товарної) у їх послідовному перетворенні одна в одну зробив Аристотель [9]. Однак він ще не визначає їх як особливу вартість, не визначає їх особливу взаємодію як капітал. Хоча саме він вперше вивів формулу цієї взаємодії «Гроші-Товар-Гроші» (ГТГ) у своїй хрематистиці. Його хрематистика походила від «хреми», як вартості у формі майна,

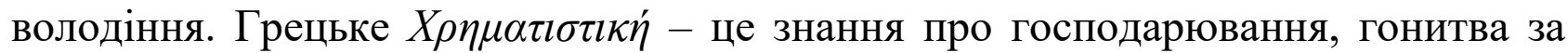
грошима, в основі якої лежить діяльність 3 метою задоволення потреб та отримання прибутку [10]. Але Аристотель не зрозумів, що саме його формула визначить у майбутньому зовсім нову, особливу вартість - сучасний капітал. Й навіть Маркс використовує цю формулу не для визначення сутності капіталу, а для критики капіталізму. Тому «капітал» Маркс визначає як «...вартість, яка створює додаткову вартість, тобто капітал - це зростаюча вартість». 
Класики А. Сміт і Д. Рікардо (та й наступні покоління економістів) у з'ясуванні сутності капіталу в порівнянні з Аристотелем зробили навіть крок назад [11]. Вони не знали формул ГТГ і ГТГ1 Аристотеля. Тому вони ототожнювали капітал 3 самими різними формами вартості, а не тільки 3 грошовою и товарною.

Отож А. Сміт до капіталу відносив лише ту частину запасів, яка призначена для подальшого виробництва і приносить дохід. 3 точки зору Д. Рікардо, капітал - це накопичений труд або все те, що бере участь у виробництві. Франсуа Кєне (засновник школи фізіократів) стверджував, що капітал - це не гроші, а ті засоби виробництва, які можна придбати за гроші. Джон Стюарт Мілль: капітал - це попередньо накопичений матеріалізований запас продуктів минулої праці, який авансується на придбання засобів виробництва і робочої сили. Жан Батист Сей: капітал є одним 3 факторів виробництва. П'єр Жозеф Прудон розглядав капітал як гроші, вважаючи провідною його формою тільки капітал позичковий. Альфред Маршалл основною рисою капіталу вважав його здатність створювати дохід. Ця здатність обумовлена продуктивністю капіталу як фактору виробництва. Кемпбелл Макконнелл і Стенлі Брю поняття «капітал» ототожнюють 3 інвестиційними ресурсами, представленими виробленими засобами виробництва - всіма видами інструментів, машин, обладнання [11].

Ніхто 3 видатних економістів світу не ототожнював капітал власне 3 повною вартістю, яка народжується в формулі «ГТГ»! Навіть Маркс до капіталу відносив тільки частку вартості, тільки додаткову вартість.

При вирішенні третьої задачі статті (встановлення головного джерела визначення сутності і змісту капіталу) автори статті прийшли до висновку, що саме формула ГТГ є законом створення особливої вартості - вартості в круговороті. Саме така повна вартість і є джерелом капіталу.

Узагальнюючи результати проведеного аналізу можна зробити висновок, що у формулі, у законі капіталу необхідно виділяти три особливі форми перетворення вартості: грошову і товарну, а також перетворення у нутрі товарної $(\mathrm{T} \rightarrow \mathrm{T} 1)$. При цьому відбувається взаємне перетворення: грошової в товарну $(\Gamma \rightarrow \mathrm{T})$ и потім товарної в грошову $(\mathrm{T} 1 \rightarrow \Gamma 1)$. Тобто, грошова і товарна форми вартості здійснюють коло, колообіг, круговорот. Ось тільки така комбінована вартість, тобто, грошова і товарна вартість тільки в колообігу, круговороті, тільки в перетворенні одна в одну, тільки така вартість $є$ капітал. Саме у цьому сутність капіталу.

I необхідно чітко розуміти, що будь-які інші форми перетворення, руху вартості (iї накопичення, зменшення, збільшення, як окремі частини кругообігу, - перетворення, рух тільки «Г $\rightarrow \mathrm{T} »$, або тільки «Т1 $\rightarrow \Gamma 1 »)$, або тільки $\mathrm{T} \rightarrow \mathrm{T} 1$ не перетворюють таку вартість у капітал.

Тому і зміст капіталу утворюють три елементи: перетворення «Г $\rightarrow \mathrm{T} »$, « $\rightarrow \mathrm{T} 1 » \mathrm{i} « \mathrm{~T} 1 \rightarrow \Gamma 1 » . \mathrm{T} \rightarrow \mathrm{T} 1$ - це елемент перетворення, рух капіталу у процесі виробництва, а «Г $\rightarrow \mathrm{T} » \mathrm{i} « \mathrm{~T} 1 \rightarrow \Gamma 1 »-$ у процесі обміну. Всі три елементи змісту капіталу створюють так звані три стадіï руху капіталу. 
Але капітал - це не вартість тільки $Г$, і не вартість тільки $T$, і не вартість тільки перетворення $\Gamma \rightarrow \mathrm{T}$, і не вартість перетворення $\mathrm{T} \rightarrow \mathrm{T} 1$, і не вартість перетворення $\mathrm{T} 1 \rightarrow \Gamma 1$. Капітал - це уся вартість у круговороті $(\Gamma \rightarrow \mathrm{T} \rightarrow \mathrm{T} 1 \rightarrow \Gamma 1)$. ( Г-Т-Т1-Г1) - це закон, сутність вартості, особливої вартості, сутність капіталу.

Висновки 3 проведеного дослідження. Вирішення поставлених задач привело до отримання таких результатів:

- Були встановлені джерела, витоки, причини і особливості появи терміну і поняття «капітал».

- Зроблена оцінка визначення капіталу як вартості різними поколіннями економістів.

- Визначене головне джерело визначення сутності і змісту капіталу формули простого (тобто, натурального), або товарного господарства.

- Визначена сутність капіталу як грошова і товарна вартість тільки в колообігу, круговороті, тільки в перетворенні одна в одну.

- Визначений зміст капіталу, який включає три елементи в їх тісному зв'язку, в перетворенні: грошової вартості у товарну; товарної в нову товарну; нової товарної вартості у нову грошову.

Визначення сутності i змісту капіталу буде сприяти підвищенню розуміння поняття, сутності капіталу і ефективності практики господарської діяльності.

\section{Перелік посилань:}

1. Капитал. Википедия: веб-сайт. URL: https://ru.wikipedia.org/wiki/\%D0\%9A\%D0\%B0\%D0\%BF\%D0\%B8\%D1\%82\%D0 \%B0\%D0\%BВ (дата звернення: 18.09.2021).

2. Капітал. Вікіпедія: веб-сайт. URL: https://uk.wikipedia.org/wiki/\%D0\%9A\%D0\%B0\%D0\%BF\%D1\%96\%D1\%82\%D0 \%B0\%D0\%BB (дата звернення: 18.09.2021).

3. Облік і фінанси АПК. Освітній портал: веб-сайт. URL: http://magazine.faaf.org.ua/ekonomichna-sutnist-kapitalu.html (дата звернення: 18.19.2021).

4. Сутність і форми капіталу. Національна економіка Білорусі: веб-сайт. URL: https://epi.cc.ua/suschnost-formyi-kapitala.html (дата звернення: 18.09.2021).

5. Сутність та форми капіталу. Кругообіг капіталу. Основний та оборотний капітал, зношення та амортизація. Файловий архів: веб-сайт. URL: https://studfile.net/preview/5782760/page:7/ (дата звернення: 18.09.2021).

6. Круговорот капіталу та його функціональні форми. BUKLIB: вебсайт. URL: https://buklib.net/books/28546/ (дата звернення: 18.09.2021).

7. Капітал. СЛОВНИК: веб-сайт. URL: https://slovnyk.ua/index.php?swrd=\%D0\%9A\%D0\%B0\%D0\%BF\%D1\%96\%D1\%82 $\% \mathrm{D} 0 \% \mathrm{~B} 0 \% \mathrm{D} 0 \% \mathrm{BB}$ (дата звернення: 18.09.2021).

8. Термінологічний словник. Фінмоніторинг: веб-сайт. URL: http://finmonitoring.in.ua/wp-content/uploads/2018/12/terminologichnijslovnik_finmonitoring.pdf (дата звернення: 18.09.2021). 
9. Політична економія. ОДЕСБКИЙ НАЦІОНАЛЬНИЙ ЕКОНОМІЧНИЙ УНІВЕРСИТЕТ: веб-сайт. URL: http://oneu.edu.ua/wpcontent/uploads/2017/12/np_2014.pdf (дата звернення: 18.09.2021).

10. Хрематистика. Вікіпедія:

веб-сайт.

URL: https://uk.wikipedia.org/wiki/\%D0\%A5\%D1\%80\%D0\%B5\%D0\%BC\%D0\%B0\%D1 $\% 82 \% \mathrm{D} 0 \% \mathrm{~B} 8 \% \mathrm{D} 1 \% 81 \% \mathrm{D} 1 \% 82 \% \mathrm{D} 0 \% \mathrm{~B} 8 \% \mathrm{D} 0 \% \mathrm{BA} \% \mathrm{D} 0 \% \mathrm{~B} 0$ (дата звернення: 18.09.2021).

11. Історія економічних вчень. Репозитарій Західноукраїнського Наиіонального Університету: веб-сайт. URL: http://dspace.wunu.edu.ua/jspui/bitstream/316497/498/1/\%D0\%86\%D1\%81\%D1\%8 2\%D0\%BE\%D1\%80\%D1\%96\%D1\%8F\%20\%D0\%B5\%D0\%BA\%D0\%BE\%D0\%B D\%D0\%BE\%D0\%BC.\%20\%D0\%B2\%D1\%87\%D0\%B5\%D0\%BD\%D1\%8C.pdf (дата звернення: 18.09.2021).

\section{References:}

1. Capital [Kapital], Vikipediya, available at: https://ru.wikipedia.org/wiki/\%D0\%9A\%D0\%B0\%D0\%BF\%D0\%B8\%D1\%82\%D0 $\%$ B0\%D0\%BB (last accessed 18.09.2021).
2. Capital
[Kapital],
Vikipediya,
available
at: https://uk.wikipedia.org/wiki/\%D0\%9A\%D0\%B0\%D0\%BF\%D1\%96\%D1\%82\%D0 $\%$ B0\%D0\%BB (last accessed 18.09.2021).

3. Accounting and finance of agro-industrial complex [Oblik i finansy APK], Osvitnii portal, available at: http://magazine.faaf.org.ua/ekonomichna-sutnistkapitalu.html (last accessed 18.09.2021).

4. The essence and forms of capital [Sutnist i formy kapitalu], Natsionalna ekonomika Bilorusi, available at: https://epi.cc.ua/suschnost-formyi-kapitala.html (last accessed 18.09.2021).

5. The essence and forms of capital. Capital cycle. Fixed and working capital, depreciation and amortization [Sutnist ta formy kapitalu. Kruhoobih kapitalu. Osnovnyi ta oborotnyi kapital, znoshennia ta amortyzatsiia], Failovyi arkhiv, available at: https://studfile.net/preview/5782760/page:7/ (last accessed 18.09.2021).

6. The capital cycle and its functional forms [Kruhovorot kapitalu ta yoho funktsionalni formy], BUKLIB, available at: https://buklib.net/books/28546/ (last accessed 18.09.2021).

7. Capital [Kapital], Slovnyk, available at: https://slovnyk.ua/index.php?swrd=\%D0\%9A\%D0\%B0\%D0\%BF\%D1\%96\%D1\%82 \%D0\%B0\%D0\%BB (last accessed 18.09.2021).

8. Terminological dictionary [Terminolohichnyi slovnyk], Finmonitoryng, available at: http://finmonitoring.in.ua/wp-content/uploads/2018/12/terminologichnijslovnik_finmonitoring.pdf (last accessed 18.09.2021).

9. Political Economy [Politychna ekonomiia], ODESKYI NATsIONALNYI EKONOMIChNYI UNIVERSYTET, available at: http://oneu.edu.ua/wpcontent/uploads/2017/12/np_2014.pdf (last accessed 18.09.2021).

10. Chrematistics [Khrematystyka], Vikipediya, available at: https://uk.wikipedia.org/wiki/\%D0\%A5\%D1\%80\%D0\%B5\%D0\%BC\%D0\%B0\%D1 
$\% 82 \% \mathrm{D} 0 \% \mathrm{~B} 8 \% \mathrm{D} 1 \% 81 \% \mathrm{D} 1 \% 82 \% \mathrm{D} 0 \% \mathrm{~B} 8 \% \mathrm{D} 0 \% \mathrm{BA} \% \mathrm{D} 0 \% \mathrm{~B} 0 \quad$ (last accessed 18.09.2021).

11. History of economic doctrines [Istoriya ekonomichnikh vchen], Repozytarii Zakhidnoukrainskoho Natsionalnoho Universytetu, available at: http://dspace.wunu.edu.ua/jspui/bitstream/316497/498/1/\%D0\%86\%D1\%81\%D1\%8 2\%D0\%BE\%D1\%80\%D1\%96\%D1\%8F\%20\%D0\%B5\%D0\%BA\%D0\%BE\%D0\%B D\%D0\%BE\%D0\%BC.\%20\%D0\%B2\%D1\%87\%D0\%B5\%D0\%BD\%D1\%8C.pdf (last accessed 18.09.2021).

\section{РЕФЕРАТИ РЕФЕРАТЫ ABSTRACTS}

\section{УДК 330.14; JEL Classification: D24}

\section{Бабайлов В. К., Левченко Я.С. УТОЧНЕННЯ СУТНОСТІ КАПІТАЛУ}

Анотація. Капітал - найважливіше поняття економіки. Однак досі існують різні його трактування. Це значно знижує ефективність економічної діяльності. Вся історія економіки і економічної думки свідчить про те, що економіка спрямована на вирішення різних проблем господарської діяльності. При цьому можно виділити п'ять основних груп проблем: осмислення у Доантичну епоху досвіду усієї господарської діяльності (управління як єдності економіки, інженерії, адміністрації і виробництва); відокремлення, визначення в Античну i Середньовічну епохи основних понять суто економічної діяльності; визначення меркантилістами і фізіократами основного джерела створення багатства (вартості), - торгівлі або сільського господарства; визначення різними школами економіки ролі держави у господарській діяльності; визначення важливих аспектів соиіальної економіки. Однак серед них існує одна актуальна проблема, яка й досі притаманна навіть декільком групам економічних проблем - це проблема визначення істиного сенсу капіталу. Вона існує ще 3 часів Аристотеля. Тому у даному контексті представляє інтерес аналіз останніх досліджень і публікацій щодо вирішення поставленної проблеми. Аналіз останніх досліджень і публікацій свідчить про те, що досі нема однозначної думки про істинний сенс капіталу. Головна причина цього в тому, що сенс капіталу шукають тільки у частинах, тільки у окремих елементах формули простого (тобто, натурального), або товарного господарства. Тому й досі відсутнє визначення його важливіших аспектів, якими $€$ cymнicmb $i$ зміст, саме які надають $70 \%$ поняття. Метою $\boldsymbol{\epsilon}$ встановлення сутності і змісту капіталу. Було вирішено такі задачі: встановлено джерела, причини і особливості появи терміну і поняття «Капітал»; оцінено визначення капіталу як вартості; визначено головне джерело капіталу. Методики дослідження. Для досягнення поставленої мети в роботі були використані такі загальнонаукові та спеціальні методи і прийоми дослідження: порівняльний аналіз наукової літератури та інформаційних джерел на основі методів порівняння, систематизації та узагальнення; узагальнення результатів аналізу і логічна генерація висновків. Результати. Встановлені джерела, причини і особливості появи терміну і поняття «Капітал». Зроблена оцінка 
визначення капіталу як вартості різними поколіннями економістів; встановлено головне джерело визначення сутності і змісту капіталу - формули простого (тобто, натурального) або товарного господарства; визначена суmність капіталу як грошова і товарна вартості тільки в круговороті; визначений зміст капіталу, який включає три елементи в їх тісному зв'язку в перетворенні: грошової вартості у товарну; товарної в нову товарну; нової товарної вартості у нову грошову. Наукова новизна: вперше встановлені сутність і зміст капіталу. Практична значимість: Визначення сутності і змісту капіталу буде сприяти підвищенню розуміння поняття, сенсу капіталу i ефективності практики господарської діяльності.

Ключові слова: капітал; сутність; зміст; вартість; товар; економіка; термін; поняття.

\section{УДК 330.14; JEL Classification: D24}

\section{Бабайлов В. К., Левченко Я. С. УТОЧНЕНИЕ СУЩНОСТИ КАПИТАЛА}

Аннотация. Капитал - важнейшее понятие экономики. Однако до сих пор существуют различные его трактовки. Это значительно снижает эффективность экономической деятельности. Вся история экономики и экономической мысли свидетельствует о том, что экономика направлена на решение различных проблем хозяйственной деятельности. При этом можно выделить пять основных групп проблем: осмысление в Доантичную эпоху опыта всей хозяйственной деятельности (управление как единства экономики, инженерии, администрации и производства); отделения, определение в Античной и Средневековой эпохах основных понятий экономической деятельности; определение меркантилистами и физиократами основного источника создания богатства (стоимости) - торговли или сельского хозяйства; определение различными школами экономики роли государства в хозяйственной деятельности; определение важных аспектов социальной экономики. Однако среди них есть одна актуальная проблема, которая до сих пор присуща даже нескольким группам экономических проблем - это проблема определения истинного смысла капитала. Она существует еще со времен Аристотеля. Поэтому в данном контексте представляет интерес анализ последних исследований и публикаций по решению поставленной проблемы. Анализ последних исследований и публикаций свидетельствует о том, что до сих пор нет однозначного мнения об истинном смысле капитала. Главная причина этого в том, что смысл капитала ищут только в частях, только в отдельных элементах формулы простого (то есть, натурального) или товарного хозяйства. Поэтому до сих пор отсутствует определение его важнейших аспектов, каковы составляют 70\% понятия. Целью является установление сущности и содержания капитала. Были решены следующие задачи: установлены источники, причины и особенности появления термина и понятия «Капитал»; оценено определение капитала как стоимости; определено главноый источник капитала. Методики исследования. Для достижения поставленной цели в работе были использованы такие общенаучные и 
специальные методы и приемы исследования: сравнительный анализ научной литературы и информационных источников на основе методов сравнения, систематизации и обобщения; обобщение результатов анализа и логическая генерация выводов. Результаты. Установлены источники, причины и особенности появления термина и понятия «Капитал». Произведена оценка определения капитала как стоимости различными поколениями экономистов; установлено главный источник определения сущности и содержания капитала формулы простого (натурального) или товарного хозяйства; определена сущность капитала как денежная и товарная стоимость только в круговороте; определен смысл капитала, который включает три элемента в их тесной связи в преобразовании: денежной стоимости в товарной; товарной в новую товарную; новой товарной стоимости в новую денежную. Научная новизна: впервые установлены сущность и содержание капитала. Практическая значимость: Определение сущности и содержания капитала будет способствовать повышению понимания понятия, смысла капитала и эффективности практики хозяйственной деятельности.

Ключевые слова: капитал; сущность; содержание; стоимость; товар; экономика; срок; понятие.

\section{UDK 330.14; JEL Classification: D24}

\section{CAPITAL}

Babailov V., Levchenko Ya. CLARIFICATION OF THE ESSENCE OF

Annotation. Capital is the most important concept of the economy. However, there are still various interpretations of it. This significantly reduces the efficiency of economic activity. The entire history of economics and economic thought testifies to the fact that the economy is aimed at solving various problems of economic activity. At the same time, five main groups of problems can be distinguished: comprehension in the Pre-Antique era of the experience of all economic activity (management as a unity of economics, engineering, administration and production); branches, definition in the Ancient and Medieval eras of the basic concepts of economic activity; determination by mercantilists and physiocrats of the main source of wealth creation (value) - trade or agriculture; determination by various schools of economics of the role of the state in economic activity; identification of important aspects of the social economy. However, among them there is one urgent problem that is still inherent in even several groups of economic problems - this is the problem of determining the true meaning of capital. It has existed since the time of Aristotle. Therefore, in this context, it is of interest to analyze the latest research and publications on solving the problem posed. Analysis of recent studies and publications indicates that there is still no single opinion about the true meaning of capital. The main reason for this is that the meaning of capital is sought only in parts, only in individual elements of the formula for a simple (that is, natural) or commodity economy. Therefore, there is still no definition of its most important aspects, which make up 70\% of the concept. The aim is to establish the nature and content of capital. The following tasks were solved: the sources, reasons and features of the emergence of the term and concept "Capital" were established; assessed the definition of capital as a value; the main source of 
capital has been identified. Research methods. To achieve this goal, the following general scientific and special methods and research techniques were used in the work: comparative analysis of scientific literature and information sources based on methods of comparison, systematization and generalization; generalization of analysis results and logical generation of conclusions. Results. The sources, reasons and features of the appearance of the term and concept "Capital" are established. The assessment of the definition of capital as a value by different generations of economists is made; established the main source of definition of the essence and content of capital - the formula of a simple (natural) or commodity economy; the essence of capital is defined as monetary and commodity value only in the circulation; defined the meaning of capital, which includes three elements in their close relationship in the transformation: monetary value in commodity; commodity into a new commodity; new commodity value into a new monetary value. Scientific novelty: the essence and content of capital have been established for the first time. Practical significance: Determination of the essence and content of capital will help to increase understanding of the concept, meaning of capital and the effectiveness of business practices.

Key words: capital; essence; content; price; product; economy; term; concept.

\section{Відомості про авторів / Сведения об авторах / About the Authors}

Бабайлов Василь Кузьмич - кандидат економічних наук, Харківський національний автомобільно-дорожній університет, доцент кафедри економіки i підприємництва, м. Харків, Україна; e-mail: super_super-kod@ukr.net; ORCID: https://orcid.org/0000-0001-5997-4561. Моб. 050-139-27-76.

Бабайлов Василий Кузьмич - кандидат экономических наук, Харьковский национальный автомобильно-дорожный университет, доцент кафедры экономики и предпринимательства, г. Харьков, Украина.

Babailov Vasil - PhD, Kharkiv National Automobile and Highway University, Associate professor of the Department of Economics and Entrepreneurship, Kharkiv, Ukraine.

Левченко Ярослава Сергіївна - доктор філософії з галузі «Соціальні та поведінкові науки», Харківський національний автомобільно-дорожній університет, доцент кафедри економіки і підприємництва, м. Харків, Україна; еmail: slavalevcenko1984@gmail.com; ORCID: http://orcid.org/0000-0002-49791101. Моб. 066-578-44-43.

Левченко Ярослава Сергеевна - доктор философии в отрасли «Социальные и поведенческие науки», Харьковский национальный автомобильно-дорожный университет, доцент кафедры экономики и предпринимательства, г. Харьков, Украина;

Levchenko Yaroslava - PhD in "Social and behavioral sciences", Kharkiv National Automobile and Highway University, Associate professor of the Department of Economics and Entrepreneurship, Kharkiv, Ukraine. 